\title{
Disease scoring systems for oral lichen planus; a critical appraisal
}

\author{
Jing Wang, Isaäc van der Waal
}

Department of Oral and Maxillofacial Surgery/Pathology, VU University medical center (VUmc) and Academic Centre for Dentistry Amsterdam (ACTA), Amsterdam, The Netherlands

\author{
Correspondence: \\ VUmc, \\ Department of Oral and Maxillofacial Surgery/Pathology \\ P.O.Box 7057 \\ $1007 \mathrm{MB}$, Amsterdam \\ The Netherlands \\ i.vanderwaal@vumc.nl
}

Received: 03/12/2014

Accepted: 15/01/201

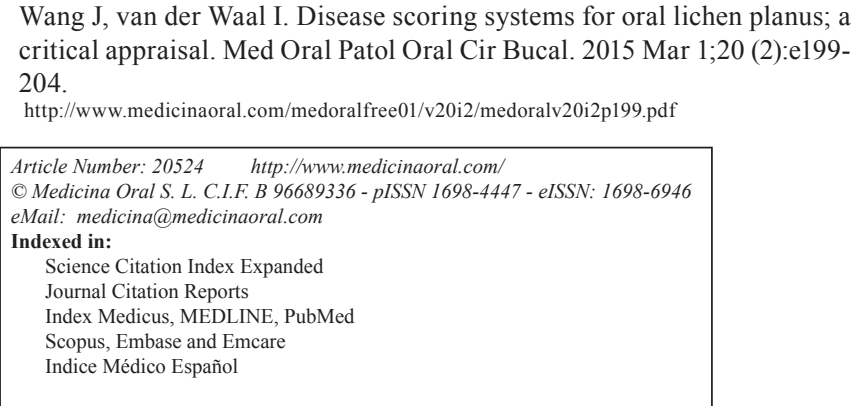

\begin{abstract}
The aim of the present study has been to critically review 22 disease scoring systems (DSSs) on oral lichen planus (OLP) that have been reported in the literature during the past decades. Although the presently available DSSs may all have some merit, particularly for research purposes, the diversity of both the objective and subjective parameters used in these systems and the lack of acceptance of one of these systems for uniform use, there is a need for an international, authorized consensus meeting on this subject. Because of the natural course of OLP characterized by remissions and exacerbations and also due to the varying distribution pattern and the varying clinical types, e.g. reticular and erosive, the relevance of a DSS based on morphologic parameters is somewhat questionable. Instead, one may consider to only look for a quality of life scoring system adapted for use in OLP patients.
\end{abstract}

Key words: Oral lichen planus, disease scoring system, classification.

\section{Introduction}

Lichen planus is a chronic autoimmune, inflammatorylike mucocutaneous disease. The exact etiopathogenesis is still unknown. The disease occurs more often in females than in males with a ratio of approximately 2:1 and mostly affects the middle-aged population. The reported prevalence of lichen planus in general is up to $5 \%$, while the prevalence of oral lichen planus (OLP) is set at $1.2 \%(1)$.

Cutaneous lichen planus (CLP) includes skin and nails. The lesions are distributed in a bilateral and more or less symmetrical pattern (2). Mucosal lichen planus
(MLP) may involve the mouth, gastrointestinal tract, larynx, genitals, ears, nose, bladder and conjunctivae of the eyes. Oral lichen planus may occur isolated or in combination with involvement of cutaneous sites or other mucosal sites. In the past, six clinical types of OLP have been recognized, being reticular, papular, plaquelike, atrophic, ulcerative/erosive, and bullous respectively (3). There is a trend nowadays to divide OLP into three categories, being 1) reticular/popular/plaque type, 2) erosive/erythematous type, and 3) ulcerative type (4). More than one subtype of OLP may occur in the same patient and subtypes may vary in the individual patients 
during the course of the disease. As in CLP, there is usually a bilateral and symmetrical distribution. Reticular OLP, which is probably the most common presentation, is usually asymptomatic while the other types may cause pain or discomfort, either spontaneously or during meals, e.g. during the use of spicy food. The clinical course of OLP is characterized by remissions and exacerbations. At present, there is no effective treatment for OLP (5). Therefore, treatment can only be symptomatic and usually consists of topical application of corticosteroids either as an ointment or a mouth rinse.

In the past decades, several disease scoring systems (DSSs) for OLP have been reported. The aim of the present study is to critically review these scoring systems.

\section{Material and Methods}

A Pubmed and Google Scholar search has been performed using the keywords "(oral) lichen planus", "scoring system", and "classification" to retrieve publications on Disease Scoring Systems for oral lichen planus in the English literature since 1980.

\section{Results}

As a result of the search a total number of 22 publications have been collected. A brief summary of the various parameters that have been used in the various DSSs is depicted in table 1. It is obvious that there is a wide variety in the objective and symptomatic parameters that have been used in the various DSSs, ranging from

Table 1. Reported Disease Scoring Systems for oral lichen planus (4,6-26).

\begin{tabular}{|c|c|c|}
\hline Author(s) & Objective morphological findings & Subjective findings (symptoms) \\
\hline Sloberg et al, 1983(6) & $\begin{array}{l}\text { Scale: } \\
\text { cured } \\
\text { improved } \\
\text { unchanged } \\
\text { mixed }\end{array}$ & $\begin{array}{l}\text { Scale: } \\
\text { cured } \\
\text { improved } \\
\text { unchanged } \\
\text { mixed }\end{array}$ \\
\hline Giustina, 1986(7) & $\begin{array}{l}\text { Scale from } 0-5: \\
0=\text { no clinical disease } \\
5=\text { severe clinical disease including ulceration }\end{array}$ & No scale \\
\hline Eisen et al, 1990(8) & $\begin{array}{l}\text { Scale from } 0-3: \\
0=\text { no clinical disease } \\
3=\text { severe clinical disease } \\
\text { Global index: } \\
0=\text { worse or no change }(\leq 20 \%) \\
1=\text { moderate improvement }(20 \%-50 \%) \\
2=\text { remarkable improvement }(50 \%-80 \%) \\
3=(\text { almost }) \text { complete improvement }(80 \%- \\
100 \%)\end{array}$ & $\begin{array}{l}\text { Scale from } 0-3: \\
0=\text { no disease } \\
3=\text { severe disease }\end{array}$ \\
\hline Holmstrup et al, 1990(9) & $\begin{array}{l}\text { Four categories for gingival lichen planus: } \\
\text { improvement } \\
\text { marked improvement } \\
\text { aggrevation } \\
\text { marked aggrevation }\end{array}$ & $\begin{array}{l}\text { Bleeding when toothbrushing } \\
\text { Pain or tenderness when eating or toothbrushing }\end{array}$ \\
\hline Silverman et al, 1991(10) & No scale & $\begin{array}{l}\text { VAS for pain } \\
1=25 \% \\
4=100 \%\end{array}$ \\
\hline $\begin{array}{l}\text { Thongprasom et al, } \\
\text { 1992(11) }\end{array}$ & $\begin{array}{l}\text { Scale from } 0-3: \\
0=\text { no lesion } \\
1=\text { mild white striae, no erythema } \\
2=\text { white striae with atrophic area }\left(\leq 1 \mathrm{~cm}^{2}\right.\end{array}$ & $\begin{array}{l}\text { Scale from } 0-1: \\
0=\text { not cured } \\
1=\text { cured: no erythema, no white striae or other } \\
\text { symptoms }\end{array}$ \\
\hline $\begin{array}{l}\text { Bagán-Sebastián et al, } \\
\text { 1992(12) }\end{array}$ & $\begin{array}{l}\text { Scale from } 0-3: \\
1=1 \text { oral site involved } \\
2=2 \text { oral sites involved } \\
3=3 \text { or more oral sites involved }\end{array}$ & No scale \\
\hline Harpenau et al, 1995(13) & $\begin{array}{l}\text { Lesions scored by area of involvement by } \\
\text { ulceration, erythema, and reticulations using an } \\
\text { intraoral grid system }\end{array}$ & No scale \\
\hline $\begin{array}{l}\text { Ramón-Fluixá et al, } \\
\text { 1999(14) }\end{array}$ & $\begin{array}{l}\text { Two clinical subtypes } \\
1=\text {.white lesions only (reticular, papular, } \\
\text { plaque-form) } \\
2=\text { atrophic-erosive } \\
\text { Affecting or not affecting other mucosal } \\
\text { surfaces than gingiva } \\
\text { Extent of the disease } \\
\text { grade } 1 \leq 25 \% \\
\text { grade } 225-75 \% \\
\text { grade } 3 \geq 75 \%\end{array}$ & No scale \\
\hline $\begin{array}{l}\text { Chainani-Wu et al, } \\
\text { 2001(15)] }\end{array}$ & $\begin{array}{l}\text { Scale for clinical signs from } 0-3: \\
0=\text { no clinical signs of the disease } \\
1=\text { reticular } \\
2=\text { atrophic } \\
3=\text { erosive } \\
\text { Severity score }=\text { signs }+ \text { symptom } \text { score }\end{array}$ & $\begin{array}{l}\text { Symptom score from } 0-3: \\
0=\text { no symptoms } \\
1=\text { mild symptoms, not affecting quality of life } \\
\text { (QOL) } \\
2=\text { moderate symptoms, affecting QOL } \\
3=\text { severe symptoms, significant affecting QOL }\end{array}$ \\
\hline Rozycki et al, 2002(16) & $\begin{array}{l}\mathrm{NR}=\text { no response } \\
\mathrm{PR}=\text { partial response defined as substantial } \\
\text { decrease in size of the lesions reported by the } \\
\text { clinician or the patient via a telephone } \\
\text { questionnaire } \\
\mathrm{CR}=\text { complete response defined as a total } \\
\text { resolution }\end{array}$ & No scale \\
\hline $\begin{array}{l}\text { Kaliakatsou et al, } \\
2002(17)\end{array}$ & $\begin{array}{l}0=\text { no lesion } \\
1=\text { white striae only } \\
2=\text { white striae and erosion } \leq 1 \mathrm{~cm}^{2} \\
3=\text { white striae with erosion } \geq 1 \mathrm{~cm}^{2} \\
4=\text { white striae with ulceration } \leq 1 \mathrm{~cm}^{2} \\
5=\text { white striae with ulceration } \geq 1 \mathrm{~cm}^{2}\end{array}$ & $\begin{array}{l}\text { VAS for pain } \\
\text { McGill pain questionnaire } \\
\text { Discomfort ranging from } 0-5(0=\text { no pain; } 5= \\
\text { unbearable pain })\end{array}$ \\
\hline
\end{tabular}


Continued.

\begin{tabular}{|c|c|c|}
\hline Hegarty et al, 2002(18) & Measurement of involved mucosal surface & VAS for pain \\
\hline $\begin{array}{l}\text { Pinboonniyom et al, } \\
2005(4)\end{array}$ & $\begin{array}{l}\text { Ten oral subsites } \\
\text { Reticular lesions }(0=\text { none; } 1=\text { presence of } \\
\text { white striae) } \\
\text { Erosive lesions }\left(0=\text { none; } 1=\text { lesion } \leq 1 \mathrm{~cm}^{2} ;\right. \\
\left.2=\text { lesions from } 1-3 \mathrm{~cm}^{2} ; 3=\text { lesions } \geq 3 \mathrm{~cm}^{2}\right) \\
\text { Ulcerative lesions }\left(0=\text { none; } 1=\text { lesion } \leq 1 \mathrm{~cm}^{2} \text {; }\right. \\
\left.2=\text { lesions from } 1-3 \mathrm{~cm}^{2} ; 3=\text { lesions } \geq 3 \mathrm{~cm}^{2}\right) \\
\text { For each of the } 3 \text { clinical signs }(\mathrm{R}, \mathrm{E}, \mathrm{U}), \text { a score } \\
\text { was derived by summation of the scores of all } \\
\text { ten areas }\end{array}$ & No scale \\
\hline Gorouhi et al, 2007(19) & $\begin{array}{l}\text { One marker lesion to assess the clinical activity } \\
\text { (scale ranging from 0-5) }\end{array}$ & $\begin{array}{l}\text { VAS for pain } \\
\text { Oral health profile score }\end{array}$ \\
\hline Escudier et al, 2007(20) & $\begin{array}{l}\text { Seventeen oral subsites } \\
\text { Subsite score (A) } \\
0=\text { no lesion } \\
1=\text { evidence of lichen planus } \\
2=\geq 50 \% \text { of buccal mucosa, dorsum of tongue, } \\
\text { floor of mouth, hard palate, soft palate or } \\
\text { oropharynx affected } \\
\text { Severity score (B) } \\
0=\text { keratosis only } \\
1=\text { keratosis with mild erythema ( } \leq 3 \mathrm{~mm} \text { from } \\
\text { gingival margin) } \\
2=\text { marked erythema (e.g. full thickness of } \\
\text { gingivae, extensive with atrophy or oedema on } \\
\text { nonkeratinized mucosa) } \\
3=\text { ulceration present } \\
\text { The Activity score was calculated as the result } \\
\text { of multiplying the Subsite score A by the } \\
\text { Severity score B }\end{array}$ & $\begin{array}{l}\text { The total score was the result of the } \\
\text { summation of the Activity score and } \\
\text { the Pain score }\end{array}$ \\
\hline Malhotra et al, 2008(21) & $\begin{array}{l}\text { Five oral subsites } \\
\text { Areas involved } \leq 50 \%(1) \text { or } \geq 50 \% \text { ( } 2) \text { of } \\
\text { tongue and buccal mucosa; for lips, gingiva and } \\
\text { palate just uninvolved ( } 0 \text { ) or involved (1) was } \\
\text { used } \\
\text { A total score was obtained by adding the scores } \\
\text { of all subsites } \\
\text { Based on the total score a grade was assigned } \\
\text { (Grade } 0=0 \text { points; grade I= } 1-3 \text { points; grade } \\
\text { II= } 4-6 \text { points; grade II= } 7-12 \text { points) } \\
\text { The Severity was expressed as: } \\
\text { Mild (asymptomatic grade I) } \\
\text { Moderate (symptomatic grade I or grade II) } \\
\text { Severe (grade III or erosive lesion of any } \\
\text { grade) }\end{array}$ & No separate score was used \\
\hline $\begin{array}{l}\text { Chainani-Wu et al, } \\
\text { 2008(22)] }\end{array}$ & $\begin{array}{l}\text { Sixteen oral subsites } \\
\text { Erythema score }(0=\text { normal, } 1=\text { mild erythema, } \\
2=\text { moderate, } 3=\text { severe }) \\
\text { Ulceration score }(0=\text { no ulceration, } 1=0-0.25 \\
\left.\mathrm{cm}^{2}, 2=0.25-1 \mathrm{~cm}^{2}, 3=1 \mathrm{~cm}^{2} \text { or greater }\right)\end{array}$ & $\begin{array}{l}\text { VAS for pain } \\
\text { Numerical rating score } \\
\text { Change in symptoms scale } \\
\text { Modified oral mucositis index }\end{array}$ \\
\hline Radfar et al, 2008(23) & Lesions measured on longest dimension & VAS for pain \\
\hline Wu et al, 2010(24) & $\begin{array}{l}\text { Seize of erosive area } \\
\text { Recurrence rate } \\
\text { Adverse effects of treatment }\end{array}$ & VAS for pain \\
\hline Park et al, 2012(25) & $\begin{array}{l}\text { The system described by Pinboonniyom et al., } \\
2005[4] \text { plus pain score }\end{array}$ & Numerical rating score \\
\hline Kaplan et al, 2012(26) & $\begin{array}{l}\text { Clinical severity defined as the number of oral } \\
\text { locations involved (buccal, tongue, floor, } \\
\text { gingiva) }\end{array}$ & $\begin{array}{l}\text { Patients'verbal description of their } \\
\text { oral condition into } 4 \text { categories: } \\
\text { complete remission } \\
\text { partial remission } \\
\text { no change } \\
\text { exacerbation }\end{array}$ \\
\hline
\end{tabular}


just the use of a VAS score in the study from Silverman et al. (10) to a rather detailed system in the studies from Pinboonniyom et al. (4) and Escudier et al. (20).

\section{Discussion and Conclusions}

The number of collected publications on DSSs for OLP is actually higher than twenty-two, since a number of scoring systems have been used in studies on the symptomatic treatment of OLP that did not focus on the disease scoring system, as is shown in a review in 2011 of treatment interventions (27). Nevertheless, the publications, as being listed in table 1 , are representative of the various types of DSSs. Almost all of the reported DSSs are based on the extent of the disease, i.e. the number of affected oral subsites, the size of the lesions and the clinical presentation, such as reticular, erosive/erythematous or ulcerative with or without the use of scoring system for symptoms. In the various DSSs there are differences in the use of the terms activity, severity and extent of the disease. In some DSSs the erosive type of
OLP is graded as a more severe type of OLP than the reticular type, while in such studies also a pain score has been applied. In yet other DSSs the extent of the disease is used as a parameter for the severity or the activity of OLP.

Remarkably, there is only one study in which two of the reported DSSs have been compared for their applicability (28); not surprisingly, the authors of that study recommended to design a uniform scoring system. Indeed, due to the diversity of both the objective and subjective parameters that have been used in the various DSSs it impossible to compare the results obtained from different studies on the treatment of oral lichen planus.

Because of its natural course of remissions and exacerbations, sometimes lifelong, and also due to the varying distribution pattern and the varying clinical types, e.g. reticular and erosive (Figs. 1 and 2), the use of a DSS for the assessment of treatment results in OLP is rather questionable.

Silverman did not use objective, morphological param-

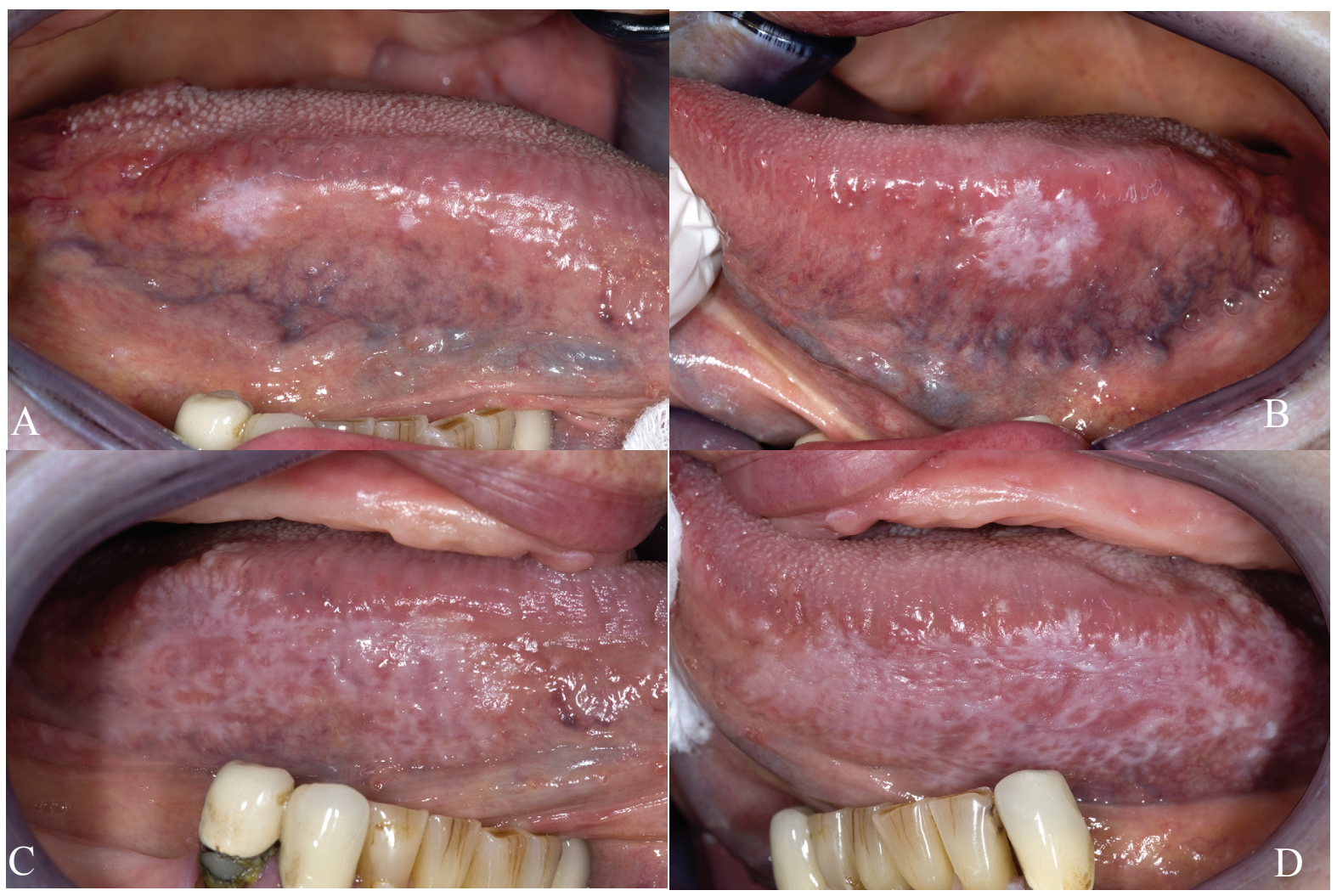

Fig. 1. Plaque-type lichen planus on the borders of the tongue; mild symptoms $(a, b)$; same patients after two months; symptoms unchanged as reported by the patient $(\mathrm{c}, \mathrm{d})$. How to incorporate the morphological changes in a disease scoring system? A quality of life scoring system may be more useful. 

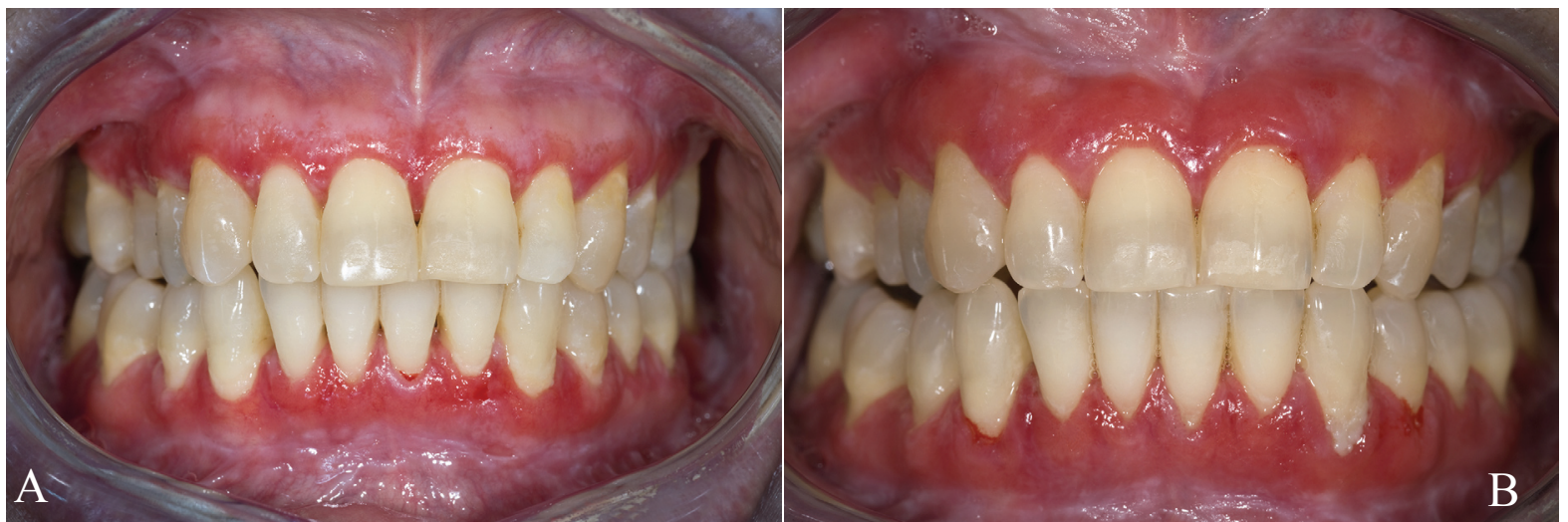

Fig. 2. Erosive lichen planus in the upper and lower gingiva; mild symptoms, mainly consisting of bleeding on toothbrushing (a); same patient after six months; symptoms unchanged as reported by the patient (b). How to incorporate the morphological changes in a disease scoring system? A quality of life scoring system may be more useful.

eters in his study but merely used a visual analog scale scale (VAS) for pain (10). With regard to gingival OLP one may question whether pain alone is a proper parameter. Patients with erosive OLP of the gingiva may not so much complain of pain but rather of bleeding on toothbrushing; in some of these patients the main complaint may even be an aesthetic one. In this respect, one may consider to develop a symptomatic scoring system for patients with OLP of the gingiva only. Yet other patients with OLP only report pain or discomfort when eating spicy food. Therefore, as has been mentioned already by several authors $(15,19)$, the use of a quality of life scoring system (29), adjusted for use in OLP patients, may be considered, perhaps even as the only parameter for the assessment of treatment results.

In conclusion, the presently available disease scoring systems for oral lichen planus may all have some merit, particularly for research purposes. Because of the diversity of these systems and the lack of acceptance of one of these systems for uniform use, there is a need for an international, authorized consensus meeting on this subject. One actually may consider to only design a quality of life scoring system adapted for use in OLP patients.

\section{References}

1. McCartan BE, Healy CM. The reported prevalence of oral lichen planus: a review and critique. J Oral Pathol Med. 2008;37:447-53. 2. Al-Hashimi I, Schifter M, Lockhart PB, Wray D, Brennan M, Migliorati CA, et al. Oral lichen planus and oral lichenoid lesions: diagnostic and therapeutic considerations. Oral Surg Oral Med Oral Pathol Oral Radiol Endod. 2007;103 Suppl:S25.e1-12.

3. Andreasen JO. Oral lichen planus. 1. A clinical evaluation of 115 cases. Oral Surg Oral Med Oral Pathol. 1968;25:31-42.

4. Piboonniyom SO, Treister N, Pitiphat W, Woo SB. Scoring system for monitoring oral lichenoid lesions: a preliminary study. Oral Surg Oral Med Oral Pathol Oral Radiol Endod. 2005;99:696-703.

5. Thongprasom K, Carrozzo M, Furness S, Lodi G. Interventions for treating oral lichen planus. Cochrane Database Syst Rev. 2011;7:CD001168.
6. Sloberg K, Hersle K, Mobacken H, Thilander H. Severe oral lichen planus: remission and main-tenance with vitamin A analogues. J Oral Pathol. 1983;12:473-7.

7. Giustina TA, Stewart JCB, Ellis CN, Regezi JA, Annesley T, Woo TY, et al. Topical application of isotretinoin gel improves oral lichen planus: a double blind study. Arch Dermatol. 1986;122:534-6.

8. Eisen D, Ellis CN, Duell EA, Griffiths CEM, Voorhees JJ. Effect of topical cyclosporine rinse on oral lichen planus. A double-blind analysis. N Engl J Med. 1990;323:290-4.

9. Holmstrup P, Schiøtz AW, Westergaard J. Effect of dental plaque control on gingival lichen planus. Oral Surg Oral Med Oral Pathol. 1990;69:585-90.

10. Silverman S, Gorsky M, Lozada-Nur F, Giannotti K. A prospective study of findings and management in 214 patients with oral lichen planus. Oral Surg Oral Med Oral Pathol. 1991;72:665-70.

11. Thongprasom K, Luangjarmekorn L, Sererat T, Taweesap W. Relative efficacy of fluocinolone acetonide compared with triamcinolone acetonide in treatment of oral lichen planus. J Oral Pathol Med. 1992;21:456-8.

12. Bagán-Sebastián JV, Milián-Masanet MA, Peñarrocha-Diago M, Jiménez Y. A clinical study of 205 patients with oral lichen planus. J Oral Maxillofac Surg. 1992;50:116-8.

13. Harpenau LA, Plemons JM, Rees TD. Effectiveness of a low dose of cyclosporine in the management of patients with oral erosive lichen planus. Oral Surg Oral Med Oral Pathol Oral Radiol Endod. 1995;80:161-7.

14. Ramón-Fluixá C, Bagán-Sebastián JV, Milián-Masanet MA, Scully C. Periodontal status in patients with oral lichen planus: a study of 90 cases. Oral Dis. 1999;5:303-6.

15. Chainani-Wu N, Silverman S, Lozada-Nur F, Mayer P, Watson JJ. Oral lichen planus: patient profile, disease progression and treatment responses. J Am Dent Assoc. 2001;132:901-9.

16. Rozycki TW, Rogers RS, Pittelkow MR, McEvoy MT, el-Azhary RA, Bruce AJ, et al. Topical tacrolimus in the treatment of symptomatic oral lichen planus: a series of 13 patients. J Am Acad Dermatol. 2002;46:27-34.

17. Kaliakatsou F, Hodgson TA, Lewsey JD, Hegarty AM, Murphy AG, Porter SR. Management of recalcitrant ulcerative oral lichen planus with topical tacrolimus. J Am Acad Dermatol. 2002;46:35-41. 18. Hegarty AM, Hodgson TA, Lewsey JD, Porter SR. Fluticasone propionate spray and be-tamethasone sodium phosphate mouthrinse: a randomized crossover study for the treatment of symptomatic oral lichen planus. J Am Acad Dermatol. 2002;47:271-9.

19. Gorouhi F, Solhpour A, Beitollahi JM, Afshar S, Davari P, Hashemi $\mathrm{P}$, et al. Randomized trial of pimecrolimus cream versus triamcinolone acetonide paste in the treatment of oral lichen planus. J Am Acad Dermatol. 2007;57:806-13. 
20. Escudier M, Ahmed N, Shirlaw P, Setterfield J, Tappuni A, Black $\mathrm{MM}$, et al. A scoring system for mucosal disease severity with special reference to oral lichen planus. Br J Dermatol. 2007;157:765-70.

21. Malhotra AK, Khaitan BK, Sethuraman G, Sharma VK. Betamethasone oral mini-pulse therapy compared with topical triamcinolone acetonide $(0.1 \%)$ paste in oral lichen planus: a randomized comparative study. J Am Acad Dermatol. 2008;58:596-602.

22. Chainani-Wu N, Silverman S, Reingold A, Bostrom A, LozadaNur F, Weintraub J. Validation of instruments to measure the symptoms and signs of oral lichen planus. Oral Surg Oral Med Oral Pathol Oral Radiol Endod. 2008;105:51-8.

23. Radfar L, Wild RC, Suresh L. A comparative treatment study of topical tacrolimus and clobe-tasol in oral lichen planus. Oral Surg Oral Med Oral Pathol. 2008;105:187-93.

24. Wu Y, Zhou G, Zeng H, Xiong CR, Lin M, Zhou HM. A randomized double-blind, positive-control trial of topical thalidomide in erosive oral lichen planus. Oral Surg Oral Med Oral Pathol Oral Radiol Endod. 2010;110:188-95.

25. Park HK, Hurwitz S, Woo SB. Oral lichen planus: REU scoring system correlates with pain. Oral Surg Oral Med Oral Pathol Oral Radiol. 2012;114:75-82.

26. Kaplan I, Ventura-Sharabi Y, Gal G, Calderon S, Anavi Y. The dynamics of oral lichen planus: a retrospective clinicopathological study. Head and Neck Pathol. 2012;6:178-83.

27. Thongprasom K, Carrozzo M, Furness S, Lodi G. Interventions for treating oral lichen planus. Cochrane Database Syst Rev. 2011;7:CD001168.

28. Lopez-Jornet P, Camacho-Alonso F. Clinical assessment of oral lichen planus based on different scales. Int J Dermatol. 2010;49:272-5.

29. Slade GD. Derivation and validation of a short-form oral health impact profile. Community Dent Oral Epidemiol. 1997;25:284-90. 